Images $I_{n} .$.

\title{
Symptomatic Bochdalek hernia in an adult patient
}

\author{
Miguel F Carrascosa, ${ }^{1}$ Ismael Abascal Carrera, ${ }^{1}$ José-Antonio Saiz-Quevedo García, ${ }^{1}$ Mercedes Acebo \\ García, ${ }^{2}$ Adela Delgado Tapia, ${ }^{2}$ Antonio Cuadrado Lavín, ${ }^{3}$ José-Ramón Salcines Caviedes ${ }^{3}$
}

1Department of Internal Medicine, Hospital of Laredo-IFIMAV, Laredo, Spain

${ }^{2}$ Radiology Section, Hospital of Laredo-IFIMAV, Laredo, Spain

${ }^{3}$ Digestive Diseases Section, Hospital of Laredo-IFIMAV, Laredo, Spain

Correspondence to Miguel F Carrascosa, mcarrascosa@hlrd.scsalud.es

\section{DESCRIPTION}

A 68-year-old woman presented with a 4-week history of right-sided chest pain and dyspnoea on minimal exertion. These symptoms had begun immediately after sudden twisting and lateral flexion movements of her trunk. She denied previous blunt or penetrating trauma. The patient was born at term and delivery was normal. She had remained asymptomatic until the present hospital admission; specifically, she denied chronic dyspnoea, chest pain, vomiting, abdominal pain and postprandial fullness. Seven years earlier, a CT study had been performed to ascertain the origin of a possible right subdiaphragmatic abnormality identified on a radiograph. CT scan only disclosed a normal variant of the right liver lobe. Physical examination only revealed abolition of breath sounds on the right lower hemithorax. Chest x-ray film showed an apparent rightsided pleural effusion (figure 1A) but thoracic ultrasound scan did not confirm this suspicion. Reformatted coronal (figure 1B) and sagittal (figure 1C) CT scans revealed protrusion of bowel loops and mesenterium into the
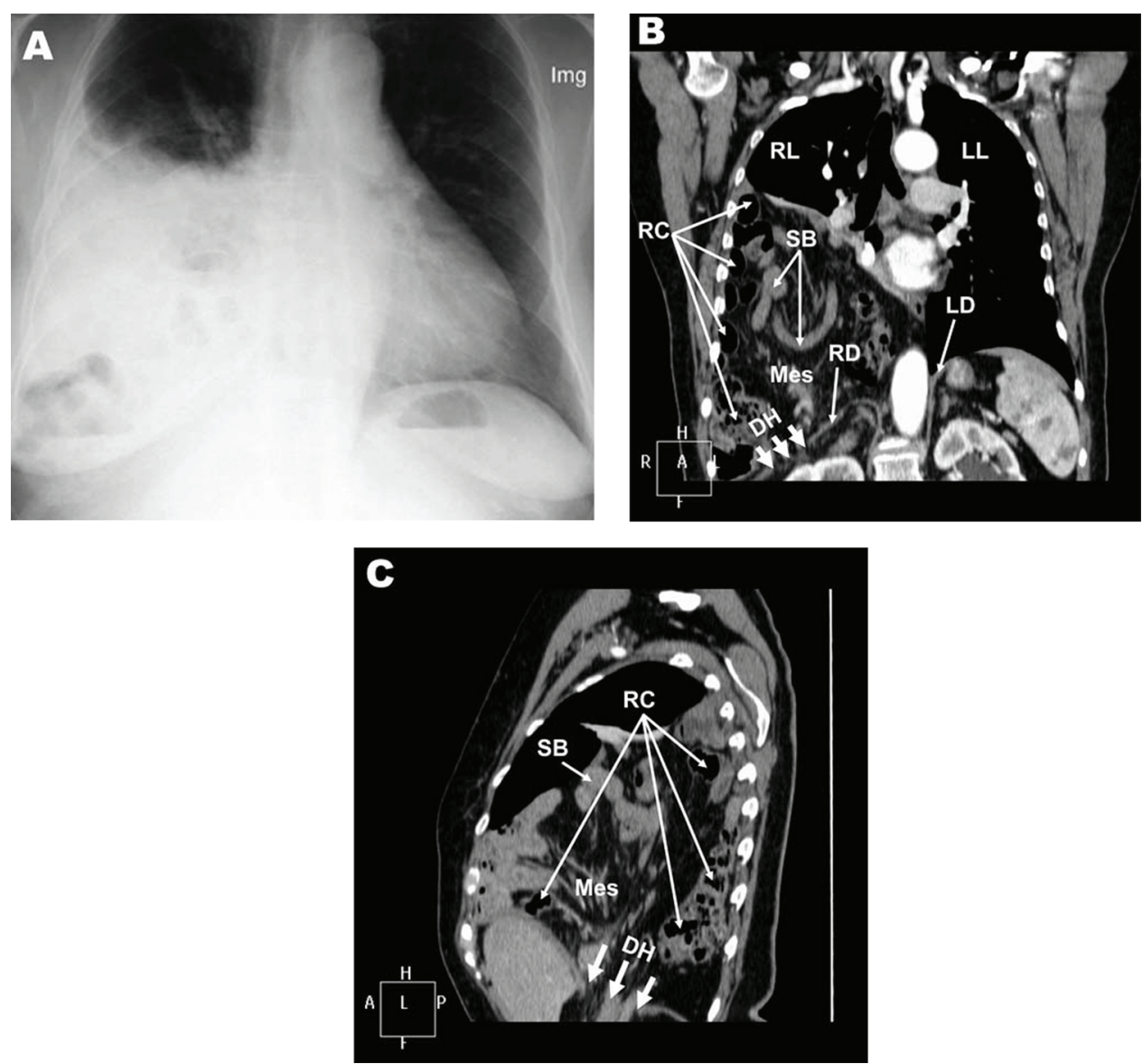

Figure 1 Chest x-ray of the patient (A) shows a possible right-sided pleural effusion. Reformatted thoracic CT scan (B) coronal section; (C) sagittal section demonstrates protrusion of abdominal contents into the right hemithorax through a posterior diaphragmatic defect. $\mathrm{DH}$, diaphragmatic hiatus; LD, left diaphragm; LL, left lung; Mes, mesenterium; RC, right colon; RD, right diaphragm; RL, right lung; $S B$, small bowel. 


\section{BMJ Case Reports}

posteromedial region of the right hemithorax through a right posterior diaphragmatic defect (thick arrows indicate the diaphragmatic hiatus). Such findings were consistent with Bochdalek hernia. Moreover, thoracic and abdominal CT showed no other congenital abnormalities. After moving back the hernia sac and the protruded organs (jejunum, ileum, part of right colon and mesenterium) to the abdominal cavity she underwent surgical diaphragmatic repair. Recovery was uneventful and the patient was discharged 12 days after the operation. Posterior transdiaphragmatic (Bochdalek) hernia was first described in 1848 as a neonatal period disease. ${ }^{12}$ Most of the Bochdalek hernias are placed on the left side and appear in children who present with acute respiratory symptoms. ${ }^{3}$ Although uncommon and often incidental in adults, this abnormality should be known and managed suitably to avoid potential complications-strangulation of the hernia contents, intestinal necrosis, haemothorax, pneumothorax. ${ }^{3}$

Competing interests None.

Patient consent Obtained.

\section{REFERENCES}

1. Bochdalek VA. Einige Betrachtungen über die Entstehung des angeborenen Zwerchfellbruches als Beitrag zur pathologischen Anatomie der Hernien. Vierteljahrsschrift für die praktische Heilkunde (Prag) 1848;19:89.

2. Kinoshita F, Ishiyama M, Honda S, et al. Late-presenting posterior transdiaphragmatic (Bochdalek) hernia in adults: prevalence and MDCT characteristics. J Thorac Imaging 2009:24:17-22.

3. Laaksonen E, Silvasti S, Hakala T. Right-sided Bochdalek hernia in an adult: a case report. J Med Case Reports 2009;3:9291.

This pdf has been created automatically from the final edited text and images.

Copyright 2010 BMJ Publishing Group. All rights reserved. For permission to reuse any of this content visit http://group.bmj.com/group/rights-licensing/permissions.

BMJ Case Report Fellows may re-use this article for personal use and teaching without any further permission.

Please cite this article as follows (you will need to access the article online to obtain the date of publication).

Carrascosa MF, Carrera IA, García J-AS-0, García MA, Tapia AD, Lavín AC, Caviedes J-RS. Enterovirus—a double act. BMJ Case Reports 2010; 10.1136/bcr.05.2010.2996, date of publication

Become a Fellow of BMJ Case Reports today and you can:

- Submit as many cases as you like

- Enjoy fast sympathetic peer review and rapid publication of accepted articles

- Access all the published articles

- Re-use any of the published material for personal use and teaching without further permission

For information on Institutional Fellowships contact consortiasales@bmigroup.com

Visit casereports.bmj.com for more articles like this and to become a Fellow 